\title{
Yield and Yield Attributes of Wheat (Triticum aestivum L.) as Influenced by Different Weeding Tools and Weed Control Measures
}

\author{
Daleshwar Rajak $^{1^{*}}$, Pradeep Prasad ${ }^{2}$ and Shambhu Sharan Kumar ${ }^{3}$ \\ ${ }^{1}$ Agricultural Engineering, ${ }^{2}$ Agronomy, Zonal Research Station, Darisai (BAU), \\ East Singhbhum, Jharkhand, India \\ *Corresponding author
}

\begin{abstract}
A B S T R A C T
\section{Keywords}

Wheat, Weeding tools, Weed control efficiency and economics

\section{Article Info}

Accepted:

17 June 2018

Available Online:

10 July 2018

A field experiment was conducted at Zonal Research Station, Darisai, East Singhbhum, Jharkhand during rabi season of 2005-06 to 2007-08 to find out the performance of different weeding tools along with weedicides for increasing the productivity of wheat. The experiments were laid out in Randomized Block Design with six treatments viz; khurpi, dutch hoe, grubber, dry land weeder, weedicide and control. The results revealed that Grubber gave maximum grain yield (27.32 $\left.\mathrm{q} \mathrm{ha}^{-1}\right)$ followed by khurpi $(26.20 \mathrm{q} / \mathrm{ha})$. The highest weeding control efficiency $(93.10 \%)$ was also recorded in grubber followed by khurpi $(96.8 \%)$ and lowest $(83.43 \%)$ was with weedicide. The plant damage was highest under dutch hoe $(2.01 \%)$ followed by dryland weeder $(1.61 \%)$ and lowest $(0.64 \%)$ with khurpi. The highest benefit cost ratio (1.25) was obtained when weeding was done with grubber.
\end{abstract}

\section{Introduction}

Wheat (Triticum aestivum L.) is an essential grain food component and is a very important commodity among cereal crops (Montazeri et al., 2005). India is second largest producer of wheat in the world after China with about $12 \%$ share in total world wheat production. Wheat is grown in India in an area of about 30 Million hectares with a production of 93 Million tones and it is a second most important staple food after rice. In Jharkhand wheat occupies 96 thousand hectares with production of 158.40 thousand tonnes Wheat provides about $20 \%$ of the total food calories of the human diet.
Weed being hardier and more competent to crop is a puissant factor which affect the crop directly or indirectly. However, with the increasing irrigation facilities and use of modern inputs the weed problem has also been intensified. Weed competes with the crop to such an extent that the crop gets smothered by the weeds. Weeds directly deplete the soil nutrients, moisture and optimize nutrient application including seed rate.

Weeds create serious problem and become a major constraints in the crop production during Rabi season in East Singhbhum area. Topographical features and climate factors of the region are such that weed growth is very 
fast. Manual weeding is difficult due to inadequate availability of labour and high labour charges at critical stages of crop weed competition. Low availability of weedicides along with its high cost is also are the major constraints in wheat production. Mechanical weeding may minimize the loss from $30 \%$ to $10 \%$ or even less. Kurstzens (2006) found that soil and residue manipulation can assist weed management by killing weeds mechanically, interfering in weed life cycle, facilitating operation and enhancing crop establishment and growth.

Weed infestation during the crop period causes more than $53 \%$ reduction in grain yield, depending on the weed densities and type of weed flora present (Singh et al., 2002). Grassy weeds emerge as a serious problem in wheat (Triticum aestivum L. emend. Fiori \& paol.), which pose a serious threat to its successful cultivation. For secured and higher production of wheat, timely and effective control of weeds is imperative. However, not much work have been undertaken on the wheat under different weeding tools along with weedicides for weed control as well as their effect on yield attributes for sub- humid tropical climate of East Singhbhum, Jharkhand, India. Thus, the present experiment was undertaken to study the performance of weeding tools for weed control as well as their effect on wheat yield.

\section{Materials and Methods}

The field experiment was conducted at Zonal Research Station, Darisai, East Singhbhum, Jharkhand during winter season of 2005-06 to 2007-08 which is located between $23^{\circ} 36^{\prime}$ North latitude, $86^{\circ} 54^{\prime}$ 'East longitude and at an altitude of $124 \mathrm{~m}$ above mean sea level. The soil of the experimental field was silt loam in texture with $\mathrm{pH}$ 6.2, organ carbon $0.58 \%$ available N, P, K 120.80, 66.55 and $140.00 \mathrm{~kg}$ $\mathrm{ha}^{-1}$ respectively and having bulk density as
$1.6 \mathrm{gm} / \mathrm{cm}^{3}$. Soil moisture at field capacity and wilting point were recorded as $17.79 \%$ and $8.5 \%$ respectively.

The experiment comprised 6 treatments viz; khurpi, dutch hoe, grubber, dry land weeder, weedicide and control in Randomized Block Design with four replications. Wheat cv. HW 2045 was sown in plots measuring $5 \mathrm{~m}$ x $4 \mathrm{~m}$ with spacing of $22 \mathrm{~cm}$. Recommended dose of fertilizer, $\mathrm{N}: \mathrm{P}: \mathrm{K}:: \quad 100: 50: 25 \mathrm{~kg} / \mathrm{ha}$ was applied in all the plots. Full dose of $\mathrm{P}$ and $\mathrm{K}$ along with one third $\mathrm{N}$ were applied at the time of sowing, and the remaining dose of $\mathrm{N}$ was applied in two equal splits after first and second irrigation. Weeding of the plots was done 30 days after sowing. Weed control efficiency (WEC) and plant damaged (\%) was calculated by the following formula.

$$
\mathrm{WCE}=\frac{\mathrm{DWC}-\mathrm{DWT}}{\mathrm{DWC}}
$$

Where,

DWC $=$ weed dry mass from the control plot (untreated)

DWT $=$ weed dry matter from treated plot

$$
\begin{aligned}
& \text { A } \\
& \begin{array}{l}
\text { Plant damage }(\%)=---- \text { x } 100 \\
\text { B }
\end{array} \\
& \text { Where, } \\
& \text { A - Number of damage plants in sample plot } \\
& \text { B - Total number of plants in sample plot }
\end{aligned}
$$

Observation on plant height, number of tillers per meter square, grains per spike, 1000 grain weight, weed count, weed dry matter were taken. The cost of cultivation was worked out for each treatment. The cost of cultivation includes expenses incurred in land preparation, intercultural operation, fertilizer, crop protection measures and harvesting with 
labour charges. The net return was evaluated by subtracting the cost of cultivation from the income obtained through produce for each treatment. The benefit cost ratio $(\mathrm{B}: \mathrm{C})$ was estimated dividing income obtained from produce by total cost of production for each treatment.

The data collected from the experiment was analysed statistically using the analysis of variance procedure, appropriate for the Randomized Block Design experiment. The test of significance was carried out at 5 per cent level.

\section{Results and Discussion}

\section{Yield attributes and yield}

A perusal of the data showed that the weeding tools had significant effect on plant height. Maximum plant height $(92.61 \mathrm{~cm})$ was observed in grubber while minimum $(82.47 \mathrm{~cm})$ was in control.

The statistical data revealed significant effect on thousand grain weight (Table 1). Thousand grain weight was maximum (39.59 g) in grubber followed by khurpi (39.07 g) whereas, minimum value (34.44 g) was recorded in control.

Different weeding tools significantly affected the number of tillers $\mathrm{m}^{-2}$ (Table 1). Statistical analysis revealed that maximum number of tillers $\mathrm{m}^{-2}$ (426.30) was recorded in grubber while the minimum number of tillers $\mathrm{m}^{-2}$ (355.10) was observed in control.

All weeding tools for weed management significantly affected grain yield. An appraisal of Table 1 shows the effect of different weeding tools on grain yield. The maximum grain yield of $27.32 \mathrm{qha}^{-1}$ was observed when weeding was done with grubber followed by khurpi (26.20 q ha $\left.{ }^{-1}\right)$. Minimum grain yield of $18.67 \mathrm{qha}^{-1}$ was observed in control plots.
Weed control measures also significantly influenced the straw yield (Table1). The highest straw yield $\left(51.32 \mathrm{q} \quad\right.$ ha $\left.^{-1}\right)$ was observed in grubber followed by khurpi (47.39 $\mathrm{q} \mathrm{ha}^{-1}$ ) and lowest straw yield (40.91 q ha ${ }^{-1}$ ) was observed in control.

The maximum yield attributes and yield were recorded in the treatment, using grubber during these three years followed by using khurpi. Tallest plant,1000-seed weight, maximum number of effective tillers $\mathrm{m}^{-2}$, grain yield and straw yield were recorded in this treatment due to weed-free condition which increases availability of nutrients, space, light and water to wheat crop.

These resulted into highest grain yield. The higher yield under weed management practices were mainly due to better growth and development of crop under low crop weed competition and greater availability of soil nutrient and other resources to crop plants. The highest production of wheat under weed management practices was also reported by Pandey et al., (2006)

\section{Weed growth}

All weed control measures reduced the weed dry weight when compared with weedy check (control). From Table1, it is observed that the lowest dry weight of weeds $\left(2.31 \mathrm{~g} / \mathrm{m}^{2}\right)$ was recorded in grubber followed by use of khurpi $\left(2.80 \mathrm{~g} / \mathrm{m}^{2}\right)$.Combined application of isoproturon@1.0 kg a.i./ha + 2,4-D @ 0.5 kg a.i./ha as post emergence recorded dry weight of weeds $\left(5.55 \mathrm{~g} / \mathrm{m}^{2}\right)$ at 30 DAS.

\section{Weed control efficiency}

The maximum weed control efficiency was observed with grubber $(93.10 \%)$ followed by khurpi $(91.64 \%)$, dutch hoe $(90.60 \%)$ dryland weeder $(88.80 \%)$ and weedicide $(83.43 \%)$ (Fig. 1). 
Table1: Effect of weeding tools on, plant height, effective tiller, 1000 seed weight, grain yield, straw yield, weeds dry weight, weed control efficiency, Plant damage and $\mathrm{B}$ : $\mathrm{C}$ ratio (Pooled data)

\begin{tabular}{|c|c|c|c|c|c|c|c|c|c|}
\hline Treatments & $\begin{array}{c}\text { Plant } \\
\text { height } \\
(\mathrm{cm})\end{array}$ & $\begin{array}{c}\text { Effecti } \\
\text { ve } \\
\text { tillers/ } \\
\text { m }^{2}\end{array}$ & $\begin{array}{c}1000 \\
\text { seed } \\
\text { Weight } \\
\text { (g) }\end{array}$ & $\begin{array}{c}\text { Grain } \\
\text { yield } \\
\left(\text { qha }^{-1}\right)\end{array}$ & $\begin{array}{c}\text { Straw } \\
\text { yield } \\
\left(\text { qha }^{-1}\right)\end{array}$ & $\begin{array}{l}\text { Weeds dry } \\
\text { weight at } 30 \\
\text { DAS }\left(\mathrm{g} / \mathrm{m}^{2}\right)\end{array}$ & $\begin{array}{c}\text { Weed } \\
\text { control } \\
\text { efficiency } \\
(\%)\end{array}$ & $\begin{array}{c}\text { Plant } \\
\text { damage } \\
(\%)\end{array}$ & $\begin{array}{l}\text { B:C } \\
\text { ratio }\end{array}$ \\
\hline $\mathrm{T}_{1}-$ Khurpi & 88.59 & 404.00 & 39.07 & 26.20 & 47.39 & 2.80 & 91.64 & 0.64 & 0.59 \\
\hline $\mathrm{T}_{2}-$ Dutch hoe & 86.78 & 389.00 & 38.20 & 23.33 & 43.47 & 3.15 & 90.60 & 2.01 & 0.82 \\
\hline T3-Grubber & 92.61 & 426.30 & 39.59 & 27.32 & 51.32 & 2.31 & 93.10 & 1.46 & 1.25 \\
\hline T4- Dryland weeder & 85.56 & 383.30 & 37.63 & 22.75 & 44.50 & 3.75 & 88.80 & 1.61 & 0.84 \\
\hline T5-Weedicide & 84.59 & 366.60 & 37.10 & 21.27 & 42.13 & 5.55 & 83.43 & 0.95 & 0.73 \\
\hline T6- Control & 82.47 & 355.10 & 34.44 & 18.67 & 40.91 & 33.49 & - & & 0.69 \\
\hline $\mathrm{CD}(5 \%)$ & 4.16 & 42.49 & 2.76 & 3.41 & 5.79 & 3.75 & - & & - \\
\hline
\end{tabular}

Fig.1 Weed control efficiency $(\%)$ of different treatments

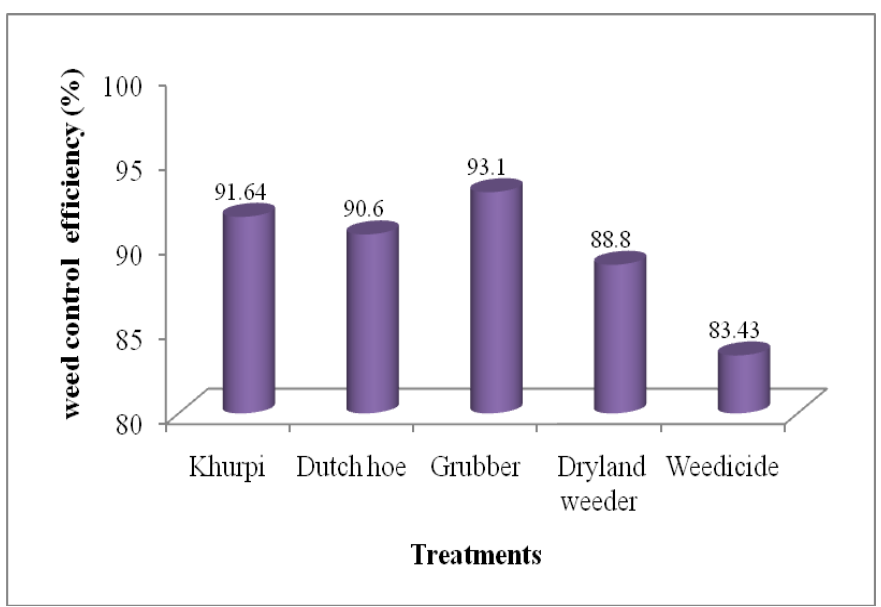

Fig.2 Plant damage (\%) by different treatments

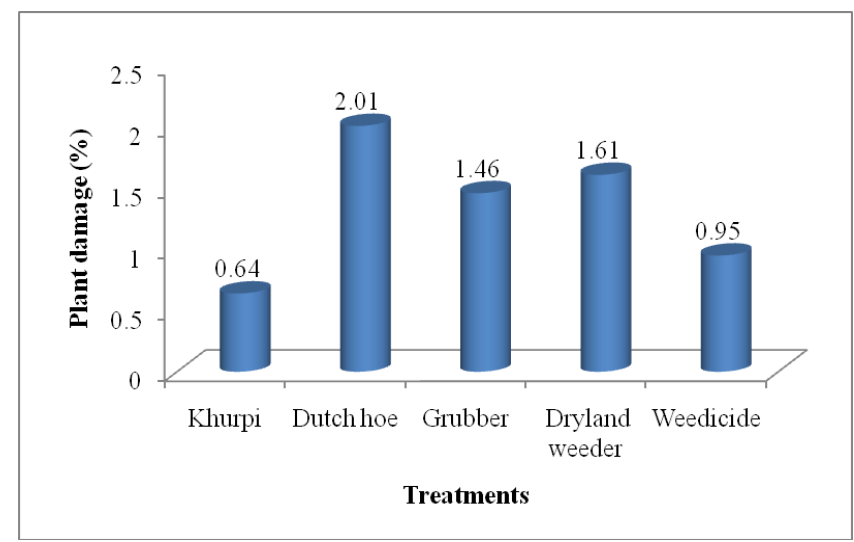


The maximum weeding control efficiency with grubber and khurpi was observed because of the capability of this hand tools to work between row to row spacing. Garg and Sharma (1998) also reported that the efficiency of Khurpi was $(82.95 \%)$ slightly higher than wheel hoe (76.91\%).

Higher percentage of plant damage was found in case of dutch hoe $(2.01 \%)$ followed by dryland weeded $(1.61 \%)$, grubber $(1.46 \%)$, weedicide $(0.95 \%)$ and khurpi $(0.64 \%)$. The higher recorded percentage of plant damage for dutch hoe might be due large width of blade in case of dutch hoe which when brought nearer to the plant during operation, caused damage to the plants by cutting either their roots or stem (Fig. 2).

\section{Economics}

The Benefit-Cost Ratio was worked out for all the treatments using net income generated and cost of cultivation of wheat. The maximum benefit cost ratio of 1.25 was noted when weeding was done with grubber and the lowest benefit cost ratio of 0.69 was recorded in control.

It is concluded that in wheat, higher yield $\left(27.32 \mathrm{q} \mathrm{ha}^{-1}\right)$ was recorded in treatment $\mathrm{T}_{3}$ (Grubber) with maximum plant height $(92.61 \mathrm{~cm})$ and effective tillers $(436.30)$. The maximum benefit cost ratio (1.25) was also noted in $\mathrm{T}_{3}$. The highest weeding efficiency $(93.10 \%)$ was found in treatment $\mathrm{T}_{3}$ (Grubber) as compared to other treatments. Thus, it can be concluded that for wheat crop weeding with grubber may be recommended for getting higher yield of wheat.

\section{References}

Garg I.K. and Sharma, V.K. 1998. Simple wheel hand hoe for interculturing in wheat crop. Intelligence. 324-325.

Kurstjens K. 2006. Study of weed management in different tillage system. Agricultural Mechanization in Asia, Africa and Latin America 39 (2): 24-26.

Montazeri M, Z and E, Baghestani M.A. 2005. Weeds and their control in wheat fields of Iran, first ed. Agric. Res. Edu. Org. Press, Tehran.

Singh, G., Singh, Y., Singh, V. P., Singh, R. K. and Sexana, A. 2002. Bio-etlicacy of herbicides in zero-till wheat in ricewheat cropping system. Indian Journal of Weed Science, 34(1\&2): 58.

Pandey, I.B., Dwivedi, D. and Prakash, S.C. 2006. Impact of method and levels of fertilizer application and weed management on nutrient economy and yield of yield (Triticum aestivum). Indian Journal of Agronomy, 51(3): 193-198.

\section{How to cite this article:}

Daleshwar Rajak, Pradeep Prasad and Shambhu Sharan Kumar. 2018. Yield and Yield Attributes of Wheat (Triticum aestivum L.) as Influenced by Different Weeding Tools and Weed Control Measures Int.J.Curr.Microbiol.App.Sci. 7(07): 2539-2543. doi: https://doi.org/10.20546/ijcmas.2018.707.298 